\title{
The Valuation Of Special Items
}

\author{
Michael J. Eames, (E-mail: Meames@scu.edu), Santa Clara University
}

James Sepe, Santa Clara University

\begin{abstract}
This research examines the value relevance of GAAP earnings, GAAP earnings excluding special items, and specific special items. We find GAAP earnings to be less value relevant than GAAP earnings adjusted to exclude special items. We find mixed results relating to the value relevance of net special items. Considering the value relevance of eight specific categories of special items, only two, in process research and development and merger related costs, appear to be significantly related to firm value. This suggests that analysts distinguish between types of special items and only specific types of special items contribute to firm value.
\end{abstract}

\section{INTRODUCTION}

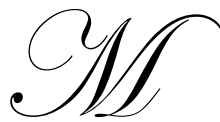

any companies now report both earnings according to generally accepted accounting principles (GAAP earnings) and pro forma earnings. On May 9, 2001, Cisco Systems, Inc. announced a loss of $\$ 2.69$ billion for the quarter ended April 28. In the same press release, Cisco reported "pro forma" earnings of $\$ 230$ million for the quarter. To obtain this pro forma value, Cisco adjusted its GAAP loss by a number of special items net of tax, including restructuring charges, an inventory write-down, and an adjustment for in-process research and development.

Standard setters are concerned with the issue of potential investor confusion when firms report multiple earnings figures. In August of 2001, the FASB proposed a new project entitled "Reporting Information about the Financial Performance of Business Enterprises." Principal reasons cited for the project were the lack of definition of elements of financial performance, inconsistent practices regarding the presentation of financial performance, and the increase in pro forma reporting (FASB 2001). The Sarbanes-Oxley Act of 2002 contains a provision that prohibits material misstatements or omissions that make pro forma numbers misleading and requires any company providing pro forma earnings to explicitly reconcile them with GAAP earnings.

The value relevance of reported earnings hinges on the ability of historical earnings to predict future earnings. This predictive ability is often referred to as earnings quality. The separation of earnings into permanent and transitory (i.e., non-recurring) components increases predictive ability because permanent earnings are commonly viewed as more relevant in assessing firm operations and value. Ramakrishnan and Thomas [1998] concluded that researchers attempting to increase the explanatory power of earnings should focus on analyzing how best to decompose earnings into permanent, transitory, and price-irrelevant components.

The reporting policies of institutions publishing analyst forecasts reflect the importance of distinguishing the permanent component of reported earnings. Zacks Investment Research presents estimates and actual EPS values based on a "proprietary definition of operating EPS before extraordinaries and non-recurring items" (Zacks 1999). The Value Line Investment Survey presents EPS figures that exclude, "unusual or one-time gains or charges in order to show what we consider to be 'normal' earnings" (Value Line 1999). Value Line specifically excludes from earnings such items as, "expenses related to the early retirement of debt, a change in accounting principle, restructuring charges, or a one-time gain or loss on the sale of assets." (Value Line 1999)

In contrast, First Call endeavors to present earnings figures that reflect the basis that the majority of covering analysts use to value the stock. Typical adjustments are for the effects of extraordinary and non-operating items. When submitting an estimate, brokers are initially free to include or exclude non-extraordinary items they may 
consider non-recurring or non-operating. However, once the majority basis is determined, First Call requires contributors to adjust their estimates to conform to this basis or be removed from the reporting population. (First Call 1999)

Company reporting of pro forma earnings reflects managements' opinion that currently reported GAAP earnings include both permanent and transitory income components and the distinction is not always apparent. Pro forma income can therefore be thought of as a disclosure to assist analysts and investors in identifying permanent earnings. For example, Amazon.com, in a recent press release announcing pro forma earnings, stated that, "Management measures the progress of the business using this pro forma information."

This research examines the value relevance of GAAP earnings in comparison to GAAP earnings adjusted for special items. Special items are the income effects that are commonly discussed as being temporary in nature. We also consider the value relevance of individual special items.

Since Ball and Brown [1968], much empirical research in accounting has addressed the role of earnings in explaining equity value. Conditions that affect the price-earnings (or return-earnings) relationship have been the focus of numerous studies. Fewer studies have addressed the explanatory power of different formulations of earnings. Burgstahler, Jiambalvo, and Sheflin [1999] determine that security prices act as if investors do not fully impound the time series properties of negative special items. Elliott and Hanna (EH) [1996] and Collins, Maydew, and Weiss [1997] document a significant increase in the number of special items in corporate income statements during the 80's and 90's. EH investigate the incremental information content of special items and conclude that unexpected earnings before write-offs are more important than are unexpected earnings in explaining returns.

Recent studies by Bradshaw, Moberg, and Sloan [2002] and Brown and Sivakumar [BS] [2000] investigate the value relevance of GAAP earnings versus the street earnings figure reported by I/B/E/S Thompson Financial. I/B/E/S and other analyst tracking services report analyst earnings estimates that are adjusted for special items. For comparison purposes, these services also present earnings values, street earnings, that reflect these same adjustments. Both studies find street earnings to be more value relevant than GAAP earnings. BS also evaluate the value relevance of COMPUSTAT earnings adjusted for the COMPUSTAT reported measure of aggregate special items. BS conclude that street earnings are more value relevant than both GAAP earnings (COMPUSTAT unadjusted earnings before discontinued operations and extraordinary items) and COMPUSTAT earnings adjusted for special items and that COMPUSTAT adjusted earnings is more value relevant than GAAP earnings. In summary, past research indicates that the market is using an earnings figure other than GAAP earnings to determine market value.

This study differs from the prior studies in an important way. Rather than employing earnings values that match analyst treatments or COMPUSTAT earnings adjusted for COMPUSTAT reported special items, we directly collect special items from company $10-\mathrm{K}$ reports. We are thus able to test the value relevance of earnings adjusted for the special items as defined by $10-\mathrm{K}$ reports, and the value relevance of individual special items. Additionally, we take a valuation approach that incorporates both earnings and book value, as opposed to the earnings only approach used in prior studies. We find that earnings net of special items is more value relevant than GAAP earnings, and that specific special items possess value relevance, while others do not. We also find that book value plays an increasingly important role in explaining equity price when earnings are not adjusted for special items.

\section{MODEL}

We employ the Ohlson (1995) model and express price as a function of both earnings and book value ${ }^{1}$.

$P_{t}=\alpha+\beta_{1} E_{t}+\beta_{2} B V_{t-1}+\varepsilon$

where

$\mathrm{P}_{\mathrm{t}} \quad=$ price per share at the end of the first quarter following fiscal year $\mathrm{t}$, 


$$
\begin{array}{ll}
\mathrm{E}_{\mathrm{t}} & =\text { earnings per share for fiscal year } \mathrm{t} \\
\mathrm{BV}_{\mathrm{t}-1} & =\text { book value per share at the beginning of year } \mathrm{t}, \text { and } \\
\varepsilon & =\text { a normally distributed error term }
\end{array}
$$

Our approach is to consider various measures of earnings and earnings components within this general framework. We initially measure earnings as GAAP earnings and obtain,

$\mathrm{P}_{\mathrm{t}}=\alpha+\beta_{1} \mathrm{GAAPE}_{\mathrm{t}}+\beta_{2} \mathrm{BV}_{\mathrm{t}-1}+\varepsilon$.

We also consider earnings before the after tax impact of special items,

$\mathrm{ADJE}_{\mathrm{t}}=\mathrm{GAAPE}_{\mathrm{t}}-\mathrm{SPEC}_{\mathrm{t}}$

where $\mathrm{SPEC}_{\mathrm{t}}=$ the after tax per share impact of special items in fiscal year $\mathrm{t}$. As an example, if an observation reported GAAPE of $\$ 1.00$ that included $\$ .20$ in after-tax asset write-downs, ADJE is $\$ 1.20$, that is, what earnings would have been without the special items. Measuring earnings as $\mathrm{ADJE}_{\mathrm{t}}$ we obtain

$\mathrm{P}_{\mathrm{t}}=\alpha+\beta_{1} \mathrm{ADJE}_{\mathrm{t}}+\beta_{2} \mathrm{BV}_{\mathrm{t}-1}+\varepsilon$.

Measuring value relevance with regression R-squares, we expect the R-square of regression (1b) using ADJE to exceed the R-square of regression (1a) using GAAPE.

Including both ADJE earnings and the after-tax value of special items (SPEC) as independent variables we obtain the following,

$\mathrm{P}_{\mathrm{t}}=\alpha+\beta_{1} \mathrm{ADJE}_{\mathrm{t}}+\beta_{2} \mathrm{SPEC}_{\mathrm{t}}+\beta_{3} \mathrm{BV}_{\mathrm{t}-1}+\varepsilon$

A significant coefficient on either component of earnings is consistent with the value relevance of the component. Furthermore, differences in the these coefficients indicate differing value relevance for the two earnings components.

Directly gathering special items from 10-K's enables us to test the value relevance of individual categories of special items. Using financial statement and footnote disclosures, we gathered reported values for the following categories of special items variables:

$\begin{array}{lll}\text { REST }= & \text { Restructuring charges } \\ \text { IPRD }= & \text { In-process research and development } \\ \text { MERG }= & \text { Merger related charges } \\ \text { AIL }= & \text { Asset impairment losses } \\ \text { LITH }= & \text { Litigation charges and income } \\ \text { IWD }= & \text { Inventory write-downs } \\ \text { GL }= & \text { Abnormal gains and losses } \\ \text { OTHER }= & \text { Other (includes insurance settlements, and other miscellaneous items) }\end{array}$

These special items are commonly discussed by analysts as appropriate adjustments to GAAP earnings and companies often exclude them from their pro forma earnings figure. It appears that COMPUSTAT also adjusts for a similar set of items. Comparing the COMPUSTAT reported value for special items (annual item 17) with the sum of our hand-gathered special items, we find that in 130 of our 191 observations the two values are equal. In 61 observations the values differ, but only three of the differences are substantial. Without knowing COMPUSTAT's adjustment process, we are unable to reconcile the differences. Our analyses employ hand-gathered special item values. To consider the various types of special items separately we construct Model 3: 
$\mathrm{P}_{\mathrm{t}}=\alpha+\beta_{1} \mathrm{ADJE}_{\mathrm{t}}+\beta_{2} \mathrm{REST}_{\mathrm{t}}+\beta_{3} \mathrm{IPRD}_{\mathrm{t}}+\beta_{4} \mathrm{AIL}_{\mathrm{t}}+\beta_{5} \mathrm{MERG}_{\mathrm{t}}+\beta_{6} \mathrm{GL}_{\mathrm{t}}$ $+\beta_{7}$ LITG $_{\mathrm{t}}+\beta_{8} \mathrm{OTHER}_{\mathrm{t}}+\beta_{9} \mathrm{IWD}_{\mathrm{t}}+\beta_{10} \mathrm{BV}_{\mathrm{t}-1}+\varepsilon$

In addition to the value relevance of the different formulations of earnings in these models, we also consider the relative importance of book value. When a firm is viewed as a going concern, book value proxies for expected future normal earnings (Ohlson, 1995). Alternatively, when the firm's going concern status becomes questionable, its book value will then proxy for the liquidation or adaptation value (Burgstahler and Dichev, 1997; and Berger et al, 1996). Given these roles of book value, it follows that when a firm's current earnings is not perceived to be a good indicator of future earnings, due to either a large transitory component in current earnings (large special items) or a change in the firm's future prospects (such as an increased possibility of liquidation), market participants will likely turn to book value for guidance in valuation, and the value-relevance of book value will increase.

Collins, Maydew, and Weiss [1997] report that the value-relevance of earnings and book value move inversely to each other. They report that while the incremental value-relevance of earnings has declined over the past forty years, the combined value-relevance of earnings and book value has not. They attribute their observed shift in value-relevance from earnings to book value to, among other things, the increase in the frequency and magnitude of special items. ${ }^{2}$ Based on this prior research, we expect the value relevance of book value to be lower in models where the earnings measure is not adjusted to exclude special items.

\section{SAMPLE INFORMATION AND VARIABLE DEFINITIONS}

We initially collected stock price at the end of the first quarter following fiscal year end (quarterly item 14), earnings before extraordinary items (annual item 20), book value of common equity (annual item 60), special items (annual item 17), income tax (annual item 16), and the number of shares used to compute annual EPS (annual item 54) data for all December fiscal year end firms in the COMPUSTAT industrial and full coverage databases for the period 1994 through 1999. To obtain a sample where earnings and special items present the potential for playing a substantial role in firm valuation, we first identified observations with positive reported earnings and with the absolute value of annual reported special items representing at least $10 \%$ of reported earnings ${ }^{3}$. From this set, we identified the 10 four-digit SIC codes with the greatest numbers of observations and for firms with these codes collected special items data from $10-\mathrm{K}$ reports.

Further restricting the sample observations, we eliminate observations for which our key variables exceeded the $99^{\text {th }}$ percentile of observed values. We thus delete observations for which EPS exceeds 15 , price per share exceeds 120 , prior period book value per share exceeds 60, special items per share exceed 5, or EPS adjusted for special items exceeds 11, and obtain a sample of 198 observations.

Table 1 Panel A presents the distribution of sample observations by year. In Panel B, we present sample observations by industry and whether net special items is positive or negative. While net negative special items is more prevalent than net positive special items, the observed difference is not significant $\left(\chi_{1}^{2}=.73, p<.25\right)$. Yet there is a highly significant difference in the frequency of positive and negative net special items across industries $\left(\chi_{9}{ }^{2}=46.47\right.$, $\mathrm{p}<.01$ ), and there appears to be a strong tendency by industry for either positive or negative net special items. In only two of the 10 industries does the incidence of positive and negative net special items differ by less than a factor of two. Panel $\mathrm{C}$ presents the distribution of $10-\mathrm{K}$ collected special items components by type, where a single firm-year observation may entail multiple types of special items. For all types of special items, zero is the most prevalent observation, in spite of the fact that for all our sample firms net special items exceed $10 \%$ of reported earnings. Abnormal gains and losses account for the majority of positive special items observations, while litigation charges and income and other account for lesser numbers of positive special items. While in Panel B we obtain no significant difference in the incidence of net positive and negative special items, in Panel $\mathrm{C}$ we see a substantial difference in the incidence of positive and negative special items $\left(\chi_{1}{ }^{2}=54.20, \mathrm{p}<.01\right)$. Panel D presents our sample distribution statistics for earnings, price, book value, and net special items per share. 
Table 1: Test Sample Characteristics

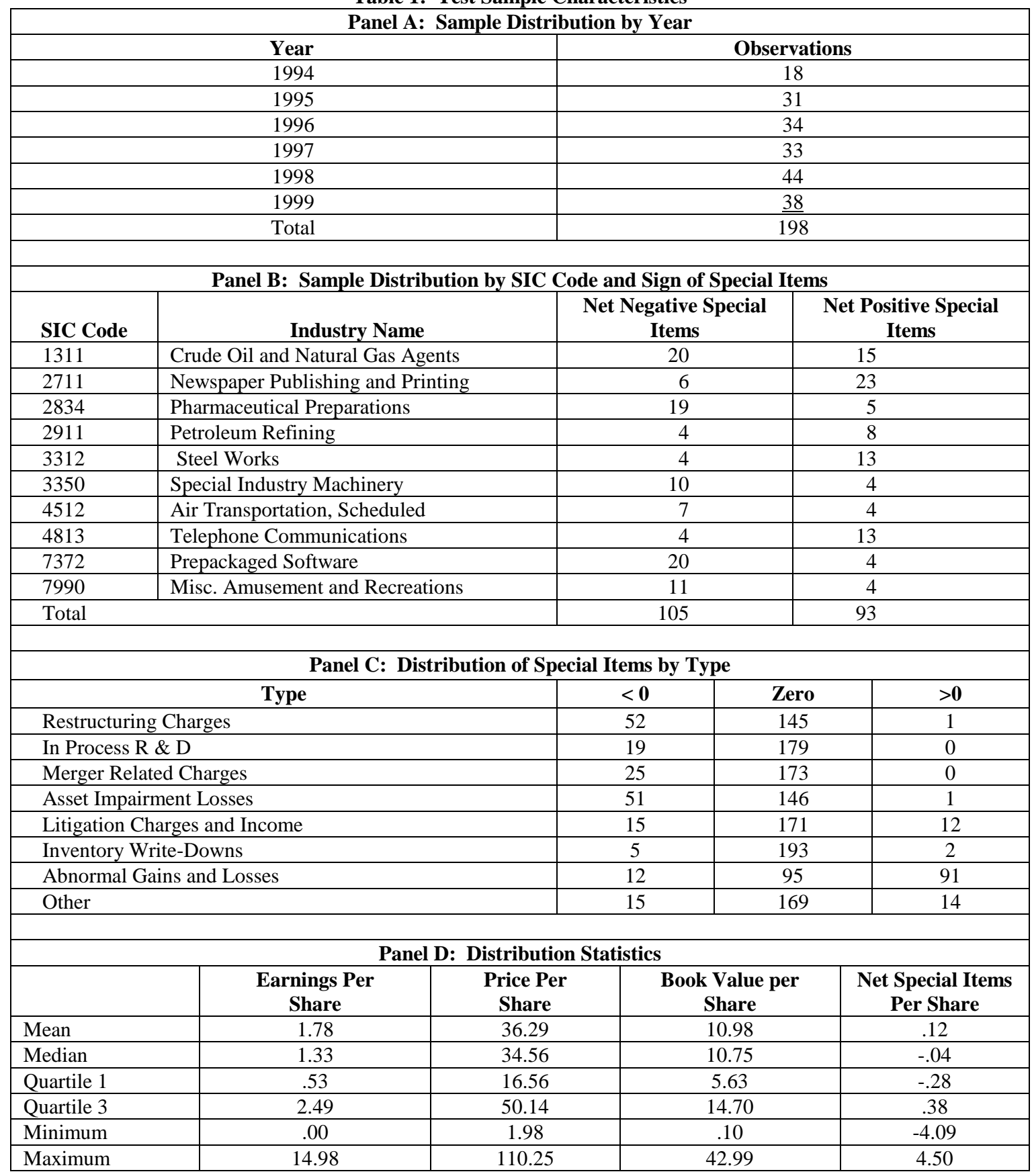

For comparison purposes, we also established a control sample consisting of all COMPUSTAT observations for the period 1994 through 1999, in our 10 selected industries, for which earnings is positive and special items are less than $10 \%$ of reported earnings. Table 2 presents descriptive information for this sample. Panel B suggests that for firms not achieving our sample threshold of net special items representing at least $10 \%$ of reported earnings, the most commonly observed value of net special items is zero. The data also suggest that there is no difference in the incidence of positive and negative net special items observations for this sample $\left(\chi_{1}^{2}=2.67, \mathrm{p}<.10\right)$ 
Table 2: Control Sample Characteristics

\begin{tabular}{|c|c|c|c|c|}
\hline \multicolumn{5}{|c|}{ Panel A: Sample Distribution by Year } \\
\hline \multicolumn{2}{|r|}{ Year } & \multicolumn{3}{|c|}{ Observations } \\
\hline \multicolumn{2}{|r|}{1994} & \multicolumn{3}{|c|}{86} \\
\hline \multicolumn{2}{|r|}{1995} & \multicolumn{3}{|c|}{86} \\
\hline \multicolumn{2}{|r|}{1996} & \multicolumn{3}{|c|}{103} \\
\hline \multicolumn{2}{|r|}{1997} & \multicolumn{3}{|c|}{109} \\
\hline \multicolumn{2}{|r|}{1998} & \multicolumn{3}{|c|}{74} \\
\hline \multicolumn{2}{|r|}{1999} & \multicolumn{3}{|c|}{$\underline{101}$} \\
\hline \multicolumn{2}{|r|}{ Total } & \multicolumn{3}{|c|}{$\overline{559}$} \\
\hline \multicolumn{5}{|c|}{ Panel B: Sample Distribution by SIC Code and Sign of Special Items } \\
\hline SIC Code & Industry Name & $\begin{array}{l}\text { Net Negative } \\
\text { Special Items }\end{array}$ & $\begin{array}{c}\text { Zero } \\
\text { Special Items }\end{array}$ & $\begin{array}{l}\text { Net Positive } \\
\text { Special Items }\end{array}$ \\
\hline 1311 & Crude Oil and Natural Gas Agents & 13 & 113 & 7 \\
\hline 2711 & Newspaper Publishing and Printing & 5 & 17 & 13 \\
\hline 2834 & Pharmaceutical Preparations & 15 & 55 & 15 \\
\hline 2911 & Petroleum Refining & 17 & 24 & 13 \\
\hline 3312 & Steel Works & 8 & 47 & 2 \\
\hline 3350 & Special Industry Machinery & 6 & 26 & 4 \\
\hline 4512 & Air Transportation, Scheduled & 3 & 21 & 8 \\
\hline 4813 & Telephone Communications & 17 & 63 & 8 \\
\hline 7372 & Prepackaged Software & 7 & 12 & 0 \\
\hline 7990 & Misc. Amusement and Recreations & 2 & 16 & 2 \\
\hline Total & & 93 & 394 & 72 \\
\hline \multicolumn{5}{|c|}{ Panel C: Distribution Statistics } \\
\hline & EPS & $\begin{array}{l}\text { Price Per } \\
\text { Share }\end{array}$ & $\begin{array}{c}\text { Book Value per } \\
\text { Share }\end{array}$ & $\begin{array}{c}\text { Net Special Items } \\
\text { Per Share }\end{array}$ \\
\hline Mean & 1.69 & 33.14 & 10.14 & .00 \\
\hline Median & 1.42 & 27.47 & 8.66 & .00 \\
\hline Quartile 1 & .66 & 16.28 & 4.64 & .00 \\
\hline Quartile 3 & 2.39 & 43.89 & 14.66 & .00 \\
\hline Minimum & .00 & 1.62 & -17.28 & -.28 \\
\hline Maximum & 10.19 & 118.14 & 42.25 & 1.08 \\
\hline
\end{tabular}

Panel C presents control sample distribution statistics for earnings, price, book value, and net special items per share. The test and control samples differ very little in relation to the observed factors other than net special items.

\section{RESULTS}

Table 3 presents regression results for models $1 \mathrm{a}, 1 \mathrm{~b}$, and 2, for both the test and control samples. For the test sample regressions, as expected, the $\mathrm{R}^{2}$ increases from Model $1 \mathrm{a}$ to Model $1 \mathrm{~b}$ (from .24 to .33 ), suggesting greater value relevance for earnings that excludes special items as opposed to GAAP earnings. Furthermore, while book value exhibits relevance in Model 1a, with the use of adjusted earnings in Model $1 \mathrm{~b}$ book value loses its significance. The non-significant $\beta_{2}$ coefficient (the special items coefficient) in Model 2 is consistent with net special items lacking value relevance. As for Model $1 \mathrm{~b}$, in Model 2 book value is not significant. Once earnings is adjusted to exclude special items, book value loses its significance. 
Table 3: Regression Results - Models 1a, 1b, And 2

\begin{tabular}{|c|c|c|c|c|c|c|c|c|c|c|c|c|c|}
\hline \multicolumn{14}{|c|}{ Model 1a: $P_{t}=\alpha+\beta_{1}$ GAAPE $_{t}+\beta_{2} B_{t}+\varepsilon$} \\
\hline \multicolumn{7}{|c|}{ Test Sample (n=198) } & \multicolumn{7}{|c|}{ Control Sample $(n=559)$} \\
\hline $\mathrm{R}^{2}$ & b 1 & $\mathrm{t}$ & b 2 & $\mathrm{t}$ & & & $\mathrm{R}^{2}$ & b 1 & $\mathrm{t}$ & b 2 & $\mathrm{t}$ & & \\
\hline .24 & 5.12 & $5.95^{*}$ & .64 & 3.04 & & & .28 & 8.65 & $12.63^{*}$ & .11 & .96 & & \\
\hline \multicolumn{7}{|c|}{ Test Sample } & \multicolumn{7}{|c|}{ Control Sample } \\
\hline \multicolumn{14}{|c|}{ Model 1b: $\mathrm{P}_{\mathrm{t}}=\alpha+\beta_{1} \mathrm{ADJE}_{\mathrm{t}}+\beta_{2} \mathrm{BV}_{\mathrm{t}}+\varepsilon$} \\
\hline $\mathrm{R}^{2}$ & b 1 & $\mathrm{t}$ & b 2 & $\mathrm{t}$ & & & $\mathrm{R}^{2}$ & b 1 & $\mathrm{t}$ & b 2 & $\mathrm{t}$ & & \\
\hline .33 & 7.82 & $8.15^{*}$ & .28 & 1.34 & & & 8.85 & $12.84 *$ & .09 & .78 & & & \\
\hline \multicolumn{7}{|c|}{ Test Sample } & \multicolumn{7}{|c|}{ Control Sample } \\
\hline \multicolumn{14}{|c|}{ Model 2: $\mathrm{P}_{\mathrm{t}}=\alpha+\beta_{1} \mathrm{ADJE}_{\mathrm{t}}+\beta_{2} \mathrm{SPEC}_{\mathrm{t}}+\beta_{3} \mathrm{BV}_{\mathrm{t}}+\varepsilon$} \\
\hline $\mathrm{R}^{2}$ & b 1 & $\mathrm{t}$ & b 2 & $\mathrm{t}$ & b 3 & $\mathrm{t}$ & $\mathrm{R}^{2}$ & b 1 & $\mathrm{t}$ & b 2 & $\mathrm{t}$ & b 3 & $\mathrm{t}$ \\
\hline .33 & 7.18 & $8.14 *$ & -1.37 & 1.92 & .26 & 1.23 & .29 & 9.15 & $13.18^{*}$ & -35.10 & $-2.73 *$ & .05 & .42 \\
\hline
\end{tabular}

Variable definitions:

$\begin{array}{ll}\mathrm{n} & =\text { number of observations } \\ \mathrm{GAAPE}_{\mathrm{t}} & =\text { the current year's (year t) earnings - excluding extraordinary items, COMPUSTAT data item \#18. } \\ \mathrm{BV}_{\mathrm{t}} & =\text { the prior year's book value, COMPUSTAT item \#60. } \\ \mathrm{P}_{\mathrm{t}} & =\text { Market value of common equity, three months after fiscal year end. } \\ \mathrm{SPEC}_{\mathrm{t}} & =\text { the total, net of tax, value of all identified special items multiplied by }-1 . \\ \text { ADJE }_{\mathrm{t}} & =\mathrm{GAAPE}_{\mathrm{t}}+\mathrm{SPEC}_{\mathrm{t}}=\text { Earnings without special items }\end{array}$

GAAPE, P, BV, and SPEC are scaled by the number of shares of common stock used to compute basic earnings per share.

For the control sample, as expected we find little difference between results for Model 1a and 1b. Certainly if special items are relatively small, there seems little point to distinguishing earnings before and after special items. Comparing results for our test and control samples for Model 1a the results appear quite similar, with a modestly higher R square value and a larger coefficient on earnings for the control sample. For Model $1 \mathrm{~b}$ the R square value for the test sample is modestly larger than for the control sample and the coefficients for earnings are quite similar. For both $1 \mathrm{a}$ and $1 \mathrm{~b}$ the coefficients on book value are not significant. Thus book value appears to be more value relevant for positive earnings firms with relatively low levels of special items. Estimation of Model 2 for the control sample data yields a minimal increase in $\mathrm{R}^{2}$ and corroborates the prior finding of a negative coefficient on special items for the test sample, however now the coefficient estimate is significant. While the signs are consistent the difference in significance may be driven by the difference in sample size.

Table 4 presents the test sample regression results for model 3. The coefficient for ADJE is positive and significant at the $1 \%$ level. The coefficients for IPRD and MERG are significant at the 5\% level. The coefficient estimates for all other special items components are not significant. The negative coefficient estimates for IPRD and MERG suggest these components of special items lead to the negative coefficient estimates observed for net special items in Model 2. Noting in Table 1 Panel C that IPRD and MERG are consistently negative, these results link greater write-offs of in process research and development and merger activities with higher firm. This may indicate future productivity gains, managements' willingness to aggressively pursue research and merger activities for productivity gains, or other related behaviors that investors interpret as desirable for enhancing firm value. The inconsistency in significance across the various components of special items is consistent with investors recognizing differences in valuation consequences associated with the various components of special items. 
Table 4: Model 3 Regression Results

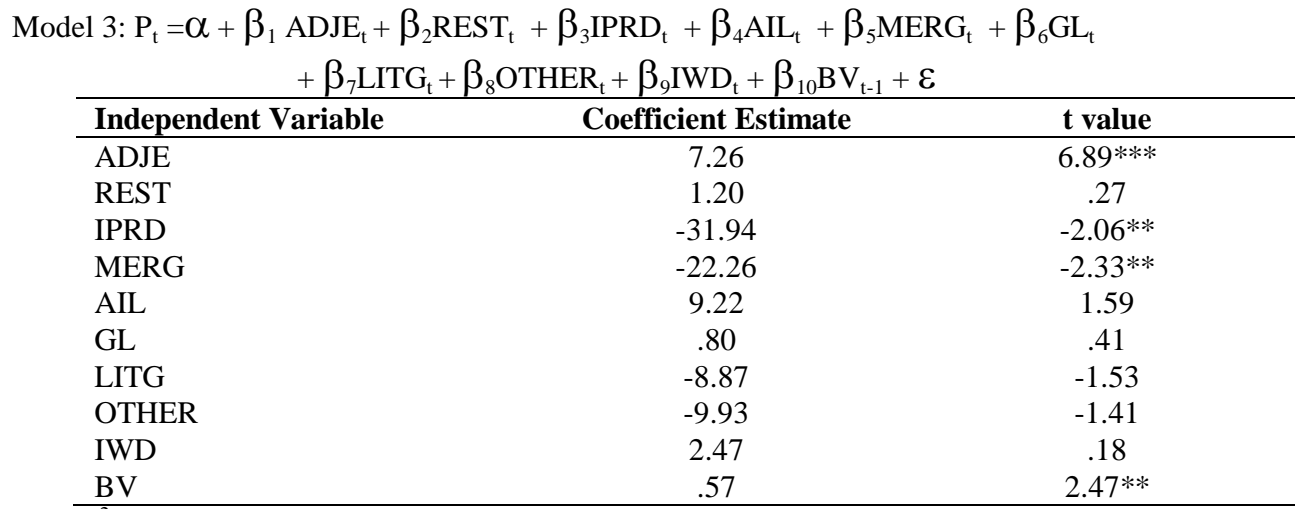

$\mathrm{R}^{2}=.37$

***, ** denotes significant at .01 and .05 levels, respectively.

$\mathrm{ADJE}_{\mathrm{t}}=$ the current year's (year $\mathrm{t}$ ) earnings - excluding extraordinary items, COMPUSTAT data item \#18.

$\mathrm{BV}_{\mathrm{t}} \quad=\quad$ the prior year's book value per share, COMPUSTAT item \#60.

$\mathrm{P}_{\mathrm{t}}=\quad$ Market value of common equity, three months after fiscal year end

REST $_{\mathrm{t}} \quad=\quad$ Restructuring costs

$\mathrm{IPRD}_{\mathrm{t}} \quad=\quad$ In-process research and development

$\mathrm{AIL}_{\mathrm{t}} \quad=\quad$ asset impairment losses

$\mathrm{MERG}_{\mathrm{t}}=$ merger costs

$\mathrm{GL}_{\mathrm{t}} \quad=\quad$ gains and losses

LITG $_{\mathrm{t}}=$ litigation gains and losses

$\mathrm{OTHER}_{\mathrm{t}}=$ other (insurance settlements and other miscellaneous items)

$\mathrm{IWD}_{\mathrm{t}} \quad=\quad$ inventory write-downs

All values are scaled by the number of common stock shares used to compute basic earnings per share.

\section{SUMMARY AND CONCLUSIONS}

Prior research has found that earnings without special items is more value relevant than GAAP earnings. In this study we take a valuation approach, as opposed to a security returns approach, to examine value relevance and come to the same conclusion. In addition, we find that the value relevance of book value varies with how earnings are measured. We also consider the value relevance of eight specific categories of special items. Of these eight, only two, in process research and development and merger related costs, appear to be significantly related to firm value. This suggests that analysts distinguish between types of special items and only specific types of special items contribute to firm value.

\section{ENDNOTES}

${ }^{1}$ A number of recent studies identify conditions where book value or earnings is relatively more important in equity valuation (for example, Burgstahler and Dichev, [1997]; Barth et al., [1998], Collins et al., [1999]).

${ }^{2}$ They also attribute the shift in value-relevance from earnings to book value to the increased incidence of negative earnings. Jan and Ou [1995] demonstrate that for firms reporting net losses, earnings explain very little of equity price, while book value is an important determinant of value. In this study, we eliminate all negative earnings observations.

${ }^{3}$ Burgstahler and Dichev (1997) show that for lower earnings levels, earnings plays a lesser role in firm valuation and the importance of book value increases. 


\section{REFERENCES}

1. Ball, R. and P. Brown. (1968). An Empirical Evaluation of Accounting Income Numbers. Journal of Accounting Research, Vol. 6, pp. 159-178.

2. Barth, M., W. Beaver, and W. Landsman. (1998). Relative Valuation Roles of Equity Book Value and Net Income as a Function of Financial Health. Journal of Accounting and Economics, 25(1), pp. 1-34.

3. Berger, P., E. Ofek, and I. Swary. (1996). Investor Valuation of the Abandonment Option. Journal of Financial Economics, 42(2), October: 257-87.

4. Bradshaw, M. and R. G. Sloan. (2002). GAAP versus The Street: An Empirical Assessment of Two Alternative Definitions of Earnings. Journal of Accounting Research, 40(1), March.

5. Brown, Lawrence D. and K. Sivakumar. (2000). Comparing the Usefulness of Three Proxies for Quarterly Income: The Street versus Two Income Numbers Obtained from Financial Statements. Working paper, Georgia State University.

6. Burgstahler, D. and I. Dichev. (1997). Earnings Adaptation and Equity Value. The Accounting Review, 72(2), April, pp. 187-215.

7. Burgstahler, D., J. Jiambalvo, and T. Shevlin. (1999). Time-series Properties and Pricing of the Special Items Component of Earnings. Working paper, University of Washington.

8. Collins, D., E. Maydew, and I. Weiss. (1997). Changes in the Value-relevance of Earnings and Book values Over the Past Forty Years. Journal of Accounting and Economics, Vol. 24, pp. 39-67.

9. Collins, D., M. Pincus, and H. Xie. (1999). Equity Valuation and Negative Earnings: The Role of Book Value of Equity. The Accounting Review 74(1), January: 29-62.

10. Elliott, J. and J. D. Hanna. (1996). Repeated Accounting Write-offs and the Information Content of Earnings. Journal of Accounting Research, Vol. 34, Supplement, pp. 135-155.

11. Financial Accounting Standards Board. (2001). Reporting Information about the Financial Performance of Business Enterprises. Proposal for a New Agenda Project, Norwalk, CT.

12. First Call. (1999). First Call Present Methodology for U.S. Earnings Estimates. Boston, MA: First Call Corporation.

13. Jan, C., and J. Ou. (1995). The Role of Negative Earnings in the Valuation of Equity Stocks. Working Paper, Santa Clara University.

14. Ohlson, J. (1995). Earnings, Book Values, and Dividends in Equity Valuation. Contemporary Accounting Research, Vol. 11, pp. 661-687.

15. Ramakrishnan, R. T. S. and J. K. Thomas. (1998). Valuation of Permanent, Transitory, and Price-irrelevant Components of Reported Earnings. Journal of Accounting, Auditing and Finance, Vol. 13, pp. 301-336.

16. Tergesen, A. (1999). Which number is the real McCoy? Business Week, October 11, pp. 177-184.

17. Value Line. (1999). How to invest in common stocks: The complete guide to using the Value Line Investment Survey. Value Line Publishing Inc.

18. Zacks. (1999). Zacks History Files with Updates. Chicago, Illinois: Zacks Investment Research, Inc. 


\section{NOTES}

